\title{
Epstein-Barr Nuclear Antigen 3
}

National Cancer Institute

\section{Source}

National Cancer Institute. Epstein-Barr Nuclear Antigen 3. NCI Thesaurus. Code C18758.

Viral nuclear antigen expressed in latency 